\title{
Revisioning the Past through Translation
}

\author{
David Josemaría Gligorovski, BA, MA, Prae Doc. \\ University of Salamanca, Spain \\ University of Vienna, Austria \\ davidgli@usal.es
}

\begin{abstract}
The emphasis of this paper is placed on the role language plays in the construction of reality. In this context, history and collective memory are conceived as two social constructs of language. The central argument is that a rearticulation of the past and a reconfiguration of the present can be carried out through translation. In this sense, translation is understood as a signification process, as a way of interaction between language and reality, as an act of searching for the voices that have been silenced in the official interpretations of history. To exemplify this, Perla, a testimony novel composed of rewritings of the official history, is analyzed from the perspective of critical historiography. The ultimate aim is to achieve a broadening and redefinition of our understanding of societal development and history through the lens of translation.
\end{abstract}

Key words: Translation; Post-Translation; Translation from below; Critical Historiography; Testimony Novel; Rewriting; Official History; De Robertis, Perla.

\section{Introduction}

In the following, we will approach languages as a discursive practice that constructs social reality, that is, we will argue from a constructivist perspective that enhances the per formative character of language. By taking language as the raw material of social reality, I will propose, in line with what other scholars like Gentzer (2017) have done in recent years, that the main mechanism in constructing reality is translation, as an epistemological, meaningcreating, and interpretation-process. In this sense, we will enlarge the definition of translation as an act of rewriting, a way of transforming social discourses, and, as Vidal (1998) refers to it, an instrument of resistance. Our main argument will be that translation is one of the most powerful tools in the revision of the past and reconceptualization of the present. Our approach is associated with what in translation studies is known as "the fictional turn', and it refers to "the recognition of fiction as an appropriate source of reflection" about translation and hermeneutic processes (Arrojo 2018:2) or as "a space of theorization" (ibid: 4).

\section{Language as a tool for constructing reality}

In his anthology "The Linguistic Turn" (1967/1990) Rorty proposed undertaking a methodological change in philosophical orientation; far from the fundamentalist philosophy and Plato's vision of the existence of a world of the abstract where the essence and substance of everything represented can be found. The latter was the predominant paradigm in the human sciences from the antiquity up until the 19th century. Rorty supported the view that "philosophical problems are problems which may be solved (or dissolved) either by reforming language or by understanding more about the language we presently use." (Rorty 1967/1990: 5), and promoted reflection on the philosophy of language. In other words, this change of perspective tried to make clear that issues of traditional epistemology were linked to language.

In another context, Barthes (1984/1994: 25) argued that "language cannot be considered as a simple instrument, whether utilitarian or decorative, of thought", because he considered it impossible to refer to a past in which human beings, as species or individuals, have lived without language or had to 'invent' the latter in order to express themselves. In his opinion, language has induced humans to become aware of themselves, and has also offered them an access to the world, this is, to a scheme of structures and forms. Following the same line of thought, Duch (2000: 156) writes that the primordial function of language consists in ordering and classifying human experience, avoiding the inclination of human thoughts towards chaos. For Bourdieu language is more an instrument of power than of communication, because language permanently defines "reality", and it "make[s] exist or -not exist- what exists" is carried out through language (Bourdieu 1982/1991: 92)

Berger and Luckmann (1966) started from the idea that the use of language is a symbolic social interaction through which our reality is created. From a constructivist point of view, these authors defend that language, as a repository of great quantities of meanings and experiences, becomes the principal means of institutionalization or legitimization, that is, of objectification of reality. In this sense, humans construct everyday life realities in their thoughts first. Then it is their thoughts that, when socially articulated, establish the veracity of the reality in which they live (Berger and Luckmann 1966: 33). In this way, reality is introduced and mediated through language, and, resorting to Potter's metaphor, it can be said that language serves as a mirror in which the world as a whole is 
reflected, while the mirror's reflections are the descriptions, representations and stories that are constructed, disseminated and deployed. In this context, the verb to construct suggests "the possibility of assembly, manufacture, the prospect of different structures as an end point, and the likelihood that different materials will be used in the fabrication. It emphasizes that descriptions are human practices, and that descriptions could have been otherwise." (Potter 1996/ 1998: 130)

It is already well known that language and speech do more than just designate things: language and speech create things (Foucault 1972: 49). So, the most important aspect of language as an abstract system of linguistic rules considered a result of psycho-physiological processes is that it represents a verbal interaction which results in social events (Voloshnikov apud Denman 2012: 167). In relation to what we have previously said about language, the process of naming things has to be understood, not as a mere process of organizing something existing, but rather as a process of creation and attribution of meaning, which has the objective of granting verifiability to referents. In other words, naming implies, in the first place, structuring, and, in the second place, constructing reality. In this sense, Barthes (1957/ 1999) introduces the concept of 'myth', not as an object or an idea, but rather as a mode or a form of signification. Myths are conceived as particular systems that unify complex semiotic units into meanings. Every myth "transforms history into nature" (ibid.: 120) or rather it first "transforms a sense into form" (ibid.: 122). Meanings arise from myths or speech acts; they are the result of linguistic signification processes which transform semiological systems into factual systems (ibid.: 123). By implication, mythical speeches impose an order, develop structures and legitimize certain forms, and thus narration is a constitutive factor of the human existence (Duch 2015: 18). In the same line of linguistic approaches to reality, Baker speaks of narratives through which we establish relationships between our experiences and our environment:

Narratives are the stories we tell ourselves and other people about the world(s) in which we live. These stories are constructed -not discovered - by us in the course of making sense of reality, and they guide our behaviour and our interaction with others. In this sense, the terms 'narrative' and 'story' can be used interchangeably. (Baker 2006: 169)

Having said that, we can affirm that it is through descriptions, representations and stories, which are considered factual and therefore reliable, that we 'build the world'. The central part of every sentence that becomes a text, of every story that is told, from the inner monologue to the simple conversation, from a newspaper article to a political manifesto, from a novel to a commercial advertisement, is the mythical/ the discursive/ the narrative. In this sense, Salmon (2013: 38) proposes storytelling as an instrument of both construction and control of reality, because in this way media, for example, superimpose artificial stories on reality, shape behaviors, and direct the flow of emotions. In conclusion, it can be said that 'reality' is a mere construct of language. Language ceases to be "a system of communication means within given society [...] which provides the content and the form of a literary work" (Levy 2002: 97) and becomes "the form itself, i.e. its meaning" (id.). In other words, reality emerges and takes shape as structures are manufactured, categories are invented, and concepts based on stories that organize describe and explain it are formulated. That is how reality comes into existence only through the descriptions of it:

Language and other codes... have a cognitive role: they provide an organized mental representation for our experience. Whatever the 'natural' structure of the world ... we handle it mentally, and in discourse, in terms of the conventional meaning-categories embodied in our society's codes. (Fowler apud Potter 1996/1998: 100)

Seen this way, language, like creator of myths, discourses, narratives, and, finally, human consciousness, becomes the raw material that constitute the fabric of social reality. According to Potter (1996/1998: 135), the different versions of reality are products of different rhetorical mechanisms in which words and syntactic structures can be imagined as 'bricks', that is to say, prefabricated pieces necessary for construction.

\section{Post-positivism and the real}

Post-positivism, which emerged as a critique of positivism at the end of the 19th century, slowly began to question the concepts that intertwined truth with what was considered 'true meaning'. In line with the argument of the previous chapter, the idea that there is a world of ideas and forms that were manifested through language and that reflected the unalterable existence of the factual and the universal turned out to be erroneous (Tymoczko 2007: 290). Thus, meaning has stopped being considered as something given, stable and untouchable, and has become something that can be constructed and modified; something that has "a posteriori nature, rather than a positivist or absolutist value" (ibid: 51). As a creation of language, meaning is not an inherent quality of the referent, but rather a performative event that has to be carried out; something emergent and constantly recreated (Vidal 2005: 6). In other words, there is not anything like a unique and unmistakable meaning that is embedded in each referent, because meaning needs to be created and negotiated again and again. 
The supposedly indissoluble links between words and things were deconceptualized by post-structuralist and deconstructionist theories (Vidal 2005: 3). These new currents of thought opened up a gulf between signs and represented objects, as they proclaimed that signifiers simply represent meanings that are not reflections but artifacts (ibid.: 6). In this way, the existence of reality was called into question.

From a poststructuralist and deconstructionist viewpoint, Arrojo (2002) defends that meanings and truths are not uttered and verbalized after being discovered, but they are, in fact, constructed and therefore they can also be deconstructed. From this it follows that our relationship with reality is mediated, for no one and nothing can be outside the domain of representation, interpretation and signification (Arrojo 2002.: 65). In this sense, we can speak of the representational nature of reality which also erases the limits between 'the true' and 'the false', between presentation and representation, between the primary and the secondary (ibid. :22), since everything is only a web of reproductions and representations.

\subsection{Representation}

In the post-positivist context, the phenomenon of representation has become the key concept in studying reality, because the latter turned out to be only an appearance, a representation of itself charged with meaning that does not reside within it. Reality depends on the way how meanings are appropriated and articulated (Žižek 2002/2005: 66). Having said that, reality, which is represented as real, is only a veil that does not allow us to recognize the interpretative part of the allegedly "real" reality, because any reality belongs to a specific , imaginary, semiological organization (ibid.: 70). The failure of reality with its innumerable layers has resulted in what Žižek calls the passion for the Real or the desire for a direct experience of reality. Since it does not correspond neither to a reference nor to a substance, reality is generated by means of models that simulate it (Baudrillard 1978: 5). Thus, the simulation masks the absence of a deep reality and reality becomes its own simulacrum (ibid.: 14). In other words, the real is just an interplay of referents. With this in mind, we can add that the only absolute weapon of power consists in establishing sets of referents that convince us of a specific social reality (ibid: 47). As Vidal says "official discourse has the power to produce collectively recognized representations, which is basically the dream of absolute power or symbolic violence." (Vidal 2019: 71).

Reality turns out to be a set of representations constructed from a particular point of view that adhere to a certain purpose. Consequently, the meaning given to reality as a social phenomenon is the product of a series of representations. Indeed, meaning is never something given, but rather it always is assigned to the present, constituted in a process of exercising power: "power is the exercise of representations, and re-presentations have the power to construct identities and serve (or deconstruct) the interests of institutions" (Vidal 2018: 88).

Therefore, it can be concluded that the real is a result of representations or mental images that are socially manifested through language as a medium. These manifestations, understood as categories and classifications, are subject to a strict code of prescriptions: they bind, convey meanings, and are in charge of organizing and shaping the notions of an apparently objective reality (Bourdieu (1982/ 1985: 87). From this perspective, "reality" is fully social, and the most "natural" classifications are always based on features that are not natural at all and that in part are the result of an arbitrary imposition (ibid.: 89).

So, what in a certain reality is considered as supposedly objective and real can always suffer changes and be reconceptualized through new representations. As we will see below, the reality of both the present and the past is the product of symbolic fiction that pretends to be an autonomous substance.

In this sense, we will study the importance of the process of constant negotiation of meaning, the translation process, and the role it plays in social constructs such as history and collective memory.

\section{Reality and Translation}

As we said before, on the basis that human beings are "linguistic beings, beings who require language in order to be" (Butler 1997: 1), narrative can be considered part of the human nature. Working from the premises that language not only represents but also constitutes reality through writings, i.e. narratives, we will extend the definition of translation to conceive it as a tool for creating narratives and counter-narratives (Baker 2016: 166). Our concept of translation corresponds to Gentzler's proposal: "think about translation as one of the most important processes that can lead to revitalizing culture, a proactive force that continually introduces new ideas, forms of expressions, and pathways for change." (Gentzler 2017: 8) In this sense, we will be arguing that the different translations of what takes or took place can be used to challenge the existence of a certain reality backed up by public institutions and official History. As we will see later, translation represents an act of intervening in the narration and the action, of (re)telling, of uncovering contradictions and discrepancies, of proposing new elements, of (de)constructing and reconstructing both the past and the present. 


\subsection{Post-Translation Studies}

From the 1970s onwards, as a consequence of the linguistic turn, language has begun to play a leading role in academic discourse in general and in historical discourse in particular, what brought to the fore the interpretative nature of reality due to the volatile nature of meaning (Aurell 2006: 637). Returning to the postpositivist theory, during the 1990s into the conceptual landscape of translation were introduced terms such as ideology, manipulation, power and ethics (Bassnettt 1999: 125). These are extralinguistic factors that not only influence written contents but also any kind of constructs in human interaction.

In the context of post-translation studies, translation is studied less as an act of exchange and enrichment between languages and cultures and more as a condition underlying not only communication but rather the human existence in its totality. This conception of translation refers to the idea that translation is the mechanism for representing and constructing the world (Vidal 2019: 5). By enlarging the understanding of language per se as a signification process, Marais (2019) proposes to study translation as a semiotic process that imposes limitations on the possibilities of signification as a result of social and cultural phenomena and manifestations (Marais 2019: 157). Thus, translation becomes a powerful practice for social, cultural, and by extension, political creation. In this way, translation can be understood as the first element in a long chain of activities that eventuate in what we know as 'reality'. A reality that is a complex product of semiotic processes that serve as social regulators.

Marais (2019) states that "[t]he 'stuff' of which translation is the process is meaning, meaning in all of its myriads of forms, shapes, shapelessness, materialities, instances." (Marais 2019: 84) . In this sense, 'to translate' becomes a means of including and excluding, of choosing, of selecting, of setting aside, of giving voice or of silencing, of forgetting, of configuring, rewriting and rerepresenting reality (Vidal 2010: 20). In the same way, translation can be considered a tool for the creation of certain representations in accordance with a particular ideology which results in the existence of a specific reality. Therefore, "to translate" is to consciously or unconsciously create a reality. (Baker apud Katan 2018: 23).

In the introduction to Translation and Power (2002: Xiii) Gentzler and Tymoczko refer to translation as 'one of the primary literary tools that larger social institutions - educational systems, arts councils, publishing firms, and even governments - had at their disposal to "manipulate" a given society in order to "construct" the kind of "culture" desired'. Consequently, we can talk about the performative capacity of translation that constantly seeks to (re)shape reality:

'Translation is definitely something one does. [...] Translation is, in this sense, a verbal play in which both a "me" and a "not-me" take active roles. It is also one that consciously and unconsciously acts with a range of other voices - intertexts or previous translations - as it performs for its audience and invites their response.' (Berman 2014: 285) In other words, a theoretical approximation to translation involves the study of "hard, falsifiable, cultural data, and the way they affect people's lives" (Bassnett and Lefevere apud Gentzler and Tymoczko 2002: xiv). Against this background, new ways of understanding both the past, in the form of history, and the present are needed. For all the aforementioned reasons, it is necessary to broaden the definition of translation and include in it interpretation, transmutation, discursive manipulation, negotiation, and adaptation that can corroborate and invalidate social rhetorics. The new notion of translation should be based on "deconstructive cultural hermeneutic methodology which separates reality to examine the order supporting it and, above all why one particular order and not some other." (Vidal 2019: 3). In the line of Duch's thinking and others, translation can be conceived as a manifestation of all that surrounds us; and also, as a creative process, a "wake-up call" that allows us to "overcome the lethargy of our very self" (id.)

Within the theory of post-translation, the translation process is understood as "an interpretive as well as an operative tool" (Gentzler 2017: 1). In response to the question "Which comes first, the pen or the sword?", this author argues that in most of the cases first the ideas change and the revolutionary fervor comes later. Therefore, he claims that revolutions that have taken place in art, politics, literature or science can be interpreted as direct consequences of acts of translation. Thus, translation becomes a vital force that plays a very important role in introducing fundamental changes and new ways of thinking (ibid.: 3), because it is the translation process that constitutes us as human beings: "we live through translation, that is, interpreting things into words and these are poured into other words and other" (Vidal 2019: 3). Thus, referring to translation we can speak of omission, distortion, (dis)adjustment, truth and lie. This perspective also opens up a new way of understanding History.

\subsection{Historical narratives as acts of translation}

Given the conception of translation as a process that implies construction, fixation and transmission of meaning, we can reach the conclusion that every episode of social reminiscence represents an act of translation in which language is the medium for the transmission of memory, for the negotiation between memory and oblivion, for the evocation of history and the reconstruction of reality. Therefore, in each historical narrative there is an underlying 
intentionality, a personal and subjective perception of the narrator, which results in a certain choice of content and mental images. Pointing out the selective nature of historiography, Steiner (1975: 29) claims that history cannot be considered objectively real, since, far from being a compilation of everything that happened, it is a systematic covering-over and suppression.

Historical narratives are not a mere reflection of past reality but rather a way of talking about past events, since what happened, the supposedly real, cannot speak for itself, cannot constitute a historical written legacy, and therefore has to be recovered, reconstructed, represented, or translated into the present. As a result of that, any story about the past ceases to be a simple narrative creation and becomes a "straightforward copy of events recounted", that is, an immediate representation of past reality (Barthes 1984/1994: 119). Having said this, it can be said that it is the historian who constructs the desired image of the past. In this sense, Bandia (2006: 48) writes: "Historical evidence is turned into 'facts' through the narrative interpretations of historians. History is indeed a process of translating evidence into facts." On account of the above, it is clear that History does not represent an archive of causes and true facts, but it rather stands for a constant process of self-reinvention, a series of transformations, successive mutations, reformulations, adaptations, that is, translations, in which different concepts are invented while, at the same time, others are lost or forgotten. In the same vein, Vidal (2018: 32) states that history can no longer be written with capital letters, because the past is nothing but a set of constructed stories, and none of them is the past itself, but a translation of it. The whole of the past is constituted by acts of translation, that is to say, narrative acts from a particular perspective, which implies a specific understanding of reality.

In light of the above, it can be inferred that historical discourse has at least two different layers: the first, the one below, covers all the additional meaning added to the facts by the storyteller in the form of moral or political conclusions; the second layer is the one that transcends the entire historical narrative, the one that forms the narrative structure, that is, the one that determines the way to tell the facts (Barthes 1989: 142). The process of recording history is a process of filling the course of the past with meaning. Therefore, the authority that studies or writes about the past does not gather facts, but rather collects meanings and relates them to each other (id.). So, the past is told by codifying and cutting out elements of past events in a certain manner: "we remember culturally, as we do individually, by conventions of emphasis, foreshortening, and omission" (Steiner 1975: 29).

In this way, translation, understood in the broadest sense of the term, represents a sieve through which we sift reality. At the same time, this metaphor seems to remind us of the danger of adopting a naive attitude towards any given reality, because the possibility of a deliberate manipulation is always there. There are many stories, many realities that can be told from different positionings depending on several factors, or in Bourdieu's terms, by virtue of the habitus and symbolic capital of who narrates them. Because of this, the official history can be considered an interpretation, a personal and subjective (re)writing that endorses one "revised" version of the past, a translation.

\subsection{Rewriting or retranslating the past}

From the perspective of critical historiography developed in the 1960s, White describes historical narrative as "verbal fictions, the contents of which are as much invented as fond, in the forms of which have more in common with their counterparts in literature then they have with those in the sciences"(White 2002: 88). In his opinion, the structures of historical narratives are based on models of (past) events like specific historical text typologies.

Moreover, if we assume that everything that comes from the past is nothing but reproductions, interpretations, i.e. translations of the occurrences, the lack of some kind of 'original material' containing what actually happened is evident. In the absence of a transcendental or an absolute truth, language shows us the way to one. This truth results from the interference of the synchronic structure system in the interpretation process of diachronic structures (Attridge 1987: 198).

In other words, history is rewritten within the present "not as a series of 'real events' (which having passed, can no longer intrude) but as the only way in which history can intervene in the present, as a theory or story of the past" (id.). In this way, the past, as a narration, becomes a translation of what happened, and the present is just a rewriting of the past.

Taking as a starting point the understanding of reality as writings, as translations of the real that construct the meaning of both the past and the present, in the following section we will try to illustrate the critical conception of history as a narrative that can translate, rewrite and reinterpret the reality of specific past events by reference to a work of literature that offers two different interpretations of particular past events.

\subsubsection{The counter narratives}

As said before, translation supposes interpreting elements and structures, and modifying representations of one reality into another. Having these notions of translation in mind, we will approach fiction as as a deconstructivist instrument, or rather, as a form of activism. 
Perla by Carolina de Robertis is an example of a novel constructed by (hi)stories that translate Argentina's official history in two different ways. It exemplifies White's central argument that history could be understood merely as a series of interpretations that have been translated over time: "[H]istory It's no less a form of fiction in the novel is a form of historical representation." (White 1978: 122). It can be sad that this novel is a record of "a marginal reality, bringing to the fore aspects of the city life that have tended to be ignored and articulating discourses from disempowered social groups" (Bielsa 2006: p. xiv), allowing voices that were silenced to be heard again.

In her novel, De Robertis translates and reinterprets the past in the broadest sense of both words: telling "from below" and giving voice to the voiceless, the unheard, the silenced. The plot of the book revolves around Perla and a male character who is floating between life and death, a desaparecido who reappears. The past is reconstructed by the voice of the disappeared who comes back from the water, Perla's voice and that of an omniscient heterodiegetic narrator. Thus, the first chapter opens up with a scene in which Perla, who is alone at home, because her mother and father have gone to spend a few days on the beach, discovers in the living room a human body that seems to be disintegrating into water, water that is gushing out of him:

'Get out,' I said. He didn't move. (p. 4) (...) Drops of water fell from his face, too copious to be sweat; they seeped from his pores, a human sponge just lifted from the river - though even sponges would stop dripping at some point, and this man's wetness had not. (p. 5)

Indeed, through the story told by the desaparecido who reappears a voice is given to those who were taken from their homes, schools and workplaces, and were never seen again. According to Erll (2016), the past is often represented in the form of images conforming to fixed patterns of shared experiences. In this sense, water is the central symbol of the novel that constantly makes reference to the place where thousands and thousands of people found death. (Erll apud García 2016: 93). The chapter ends with the scene of disappearance of the protagonist told by the narrator:

He remembers. (...) He turned the key and pushed the door open and there was Gloria, blindfolded, still as a doll. The first fist sent him to the floor, and he stayed there, there were many of them, dozens, a dozen boots around him, in his ribs, kicking, speaking, the boots were speaking, they wanted to know things, but he couldn't speak. (...) He understood that they had come for him, it was his turn, he would be gone, Gloria was right about people being taken (...) $[\mathrm{T}]$ he hood came over his head, the room went quiet, by now it was the middle of the night, he was rolled into a carpet, he was carried down the stairs of his apartment building past neighbors' doors that did not open, everybody seemed to know to keep their doors closed on such nights, and then he was in the footwell of a car that drove and drove and drove and that - he now remembers - is how he disappeared. (p. 18)

Like in the first one, in many other chapters of this novel the main narration is constantly interrupted to add previous or upcoming events, introduced by the voice of the omniscient narrator. In the second chapter, Perla has a conversation with the reappeared man who starts telling what he remembers:

'I was in the water.' It was difficult to hold his gaze. 'In the water?' 'Yes.' 'Which water?' 'All of it.' I finished my scotch and filled my glass again. 'And before that?' 'I disappeared.' (p. 22)

It should be noted again that the author rewrites and reviews the past according to the ideas of the critical historiography started by historians like Hayden White. In this context, we will not attempt to reconstruct the plot of this novel following a temporal logic, but rather, we will focus on the fragments that give evidence of the two opposing discourses, that is, the two obliquely different interpretations ("translations") that make up this story and that translate the reality (of the past) from two antagonistic perspectives. This novel uses a dichotomous frame in which the role of the victim and the role of the aggressor are constantly being reversed, depending on the point of view.

The word "desaparecido" brings back to Perla the memory of a conversation she had with her mother as a child. As we can see in the following paragraph, the political and ideological position of Perla's family, as well as the interpretation of the reality into which their lives are built, is reflected in her mother's words:

Perla, Perlita, my mother said, don't believe the lies about the disappeared. You are going to hear things in school, and I'll tell you now that they're not true, Perlita, these people are hysterical, they don't understand a lot of things. Don't say anything to them about it. Just stay quiet and remember they are confused. (p. 23)

Perla's thoughts in this chapter reflect the different interpretations that dominated the Argentinian society's thinking regarding past events after leaving the dictatorship. Here, the narrator presents two translations, two versions that differentiate between what was "truth" and what was "lie" about the disappeared; there is talk about mass graves and, at the same time, about exaggerations; shame and necessity; innocence and guilt. We see two remembrance schemes that in two different ways explain what past meant, means and will mean:

The word disappeared kept ricocheting, through rooms, down streets, in grocery stores, in plazas, in newspapers, in whispers and in wails and all tones in between. A new number of desaparecidos was calculated, denied, defended. Thirty thousand. That number was a lie from foreign groups. That number was truth that has occurred. The number 
was of people government had taken. No. It was people who simply had gone somewhere else. No. There were mass graves. There were exaggerations. They were dead. There must be survivors. El Proceso was national shame. El Proceso had been necessary. The disappeared had been innocent. The disappeared had endangered the security of the nation. (p. 26)

In this way, different narratives and counter-narratives are created (Baker 2006: 166). Later on, in the same chapter, a scene which belongs to an analepsis shows Perla as a twelve-year-old girl who refers to a story she wrote at school during the early days of the re-established democracy. In her story missing people "survived by taking in memories instead of air, craving recollection on the way the rest of humanity craves breath" (p. 27), had swollen lips because they were telling "their own stories", and "kept looking for the rift in their reality, they crack they'd slipped through, a way to go back home, or at least tell those they'd left behind what happened so they wouldn't have to worry. But the slipping-place was gone." (id.) This piece of writing, along with the act of writing it, in a way corresponds to what Spivak (1985) calls 'subaltern writing'. Perla's story provokes a great discussion at her home, because her privileged family's reality is threatened by the topics the story brings to the surface.

'We're your parents. Your mamá and I.' 'Do you want to lose us?' I shook my head. 'You want to be an orphan?' 'No.' (p. 28) [...] 'Perla,' he said, 'you are killing me.' 'I'm sorry,' I said. 'All right then,' said Mamá. 'Let's all go to bed.' (p. 29)

In contrast to the reactions she receives at home, when Perla visits Romina she is received as a heroine who has demonstrated character strength and has articulated a past that, although hidden, is still burning in secret: "The parents exclaimed, A wonderful story, we loved it, how brave of you (p. 40)". However, after having a conflict with her father and mother, Perla starts wondering if she is doing the right thing in accepting the praise at Romina's house; she no longer knows whom to believe and, at the same time, she is invaded by doubts about the veracity of the story she wrote:

[...] and a hot shame ran through me at accepting praise for this story that had brought so much trouble at home, that I willed myself to renounce, because it was a bad story, wasn't it, and I had been bad for writing it? Wasn't it an embarrassment? Hadn't it been woven out of lies? (id.)

In the following paragraph, De Robertis describes a young woman who is caught between what she has to consider a false truth and what, in reality, is a true lie. The two different translations of the past are based on two completely opposite views. Perla wonders if truth and lie can easily be discerned between the two existing versions of events. On the one hand, there is her family that took part in the repressive procedure deployed by the Armada, and on the other hand, all those people, whose deaths had been unknown or minimized:

Mamá after all, insisted that the accusations about desaparecidos were untrue; if these women in the plaza were caught up in a big mistake, unable to accept the wanderlust of their sons (and wouldn't it be good if it had always been that, if Romina's uncles had just gone roaming the world like Rimbaud! If they arrived back one day with too long hair and exotic tales to tell!).... Unless they were not delusions. Unless the people in the plaza were the ones with the truth, and I was the one who breathed in lies. (p. 43)

In the same chapter, Perla reflects on her friendship with Romina which dissolved after Romina found out that Perla's father had been an officer of the Armada. This friendship break-up Perla describes as "nothing more and nothing less so a misunderstanding" (p. 46); a misunderstanding in terms of ideas of what is or should be considered the truth: "a traffic disconnect between two poles of reality" (id.). In short, the narrator highlights the biases in the process of understanding and being understood: It seemed to me that the rift between us was larger than us, larger than either of our understandings - wasn't it? Surely that's how it was? - since to understand it fully would mean seeing things from all sides, and neither of us had done such a thing. For all I knew, no one in all of Argentina had truly seen all sides. (p. 46)

Moreover, Perla conveys the message that this is a disagreement in the way of understanding reality based on different translations, two ways of seeing things, two different approaches, like the two sides of an abyss:

Maybe no one had ever stood in the gales between men like Papá and men like Romina's uncles and somehow absorbed all of it, the whole scope of the story, every inch of shadow and light. Maybe no one had ever loved a person on both sides of that chasm. (p. 47)

In the fourth chapter, De Robertis reconstructs and rewrites the past on the basis of the memories of the man who emerged from the water. A scene in which violence, torture and murder are justified and endorsed by the prevailing discourse that translates death into a necessary instrument for social transformation and the establishment of order by authorities endowed with symbolic power:

He was on the machine. The explosions were in his mouth and on his genitals. And then they stopped, the hood raised up, he saw the composed face of a priest. Confess, my child. Father. You must cooperate. Father, please, tell them to stop, they're going to kill me. My son, how can they stop when you won't help them? I have nothing else 
to tell. I don't know anything. Confess, my son. Confess. Please, I have a wife, don't let them kill her. Death is in the hands of God. Then tell God not to kill her. The priest smiled sadly. Gods knows this is all for the good of the country. (p.60)

Here, it is clear that the discourse born out of ideological convictions is also adopted by those who represent religion as a social structure participant in the established dictatorial order. In this context, language adapts discursive concepts to the circumstances and the social needs of Power. That means, reality is translated into another reality that suits the governing structures. Therefore, the priest claims that God also agrees with what is happening, and that everything is done for the sake of the country.

In addition, the change of perspective Perla undergoes due to the appearance of the desaparecido results in a need to resignify herself. Her identity crisis is linked to the outburst that takes place in her past and the memory she has of it. She reflects on the manipulations upon which her truth is based. So, she feels an urge to rewrite her current relationships with the past. In this sense, the narratives that seek to regain the memory of the 'absent' can be considered 'reclaiming discourses':

First comes a thought, then words to carry it, and only then does a thing take shape in a concrete way. In the beginning there truly was the Word. [...] It felt good to tell the story without the context of my mother this, my father that. My own story, unhampered, as if my parents did not exist. I had never described my life that way to anyone. I felt entranced 73 by my own telling, and wondered how much of it was fiction and how much a new way of looking at the truth. (p. 92)

On the other hand, Gabriel and his mother's behavior shows a political and ideological distance with respect to Perla's father and mother. Their ideas are opposed to the convictions of Perla's family and, therefore, they organize, arrange and relate to the past, the memory of it and the present in a very different way. Gabriel takes part in public events that denounce the participants in injustice and violence and that, at the same time, aim to transform the official historical narrative.

Gabriel attended H.I.J.O.S ${ }^{1}$ meetings, he protested outside the homes of accused members of the former regime, he spent hours between midnight and dawn at bars with other people who gladly rode the rapids of political discussion with him. He engaged in similar discussions with his parents, or so he told me. His mother in particular was proud of his work. She was passionate about the subject, so much so that The Official Story ${ }^{2}$ had become her favourite film. She never tired of watching it. (p. 99)

The following paragraphs refer to episodes of sociopolitical transformation, when, in the words employed by Perla's mother, 'everything was ruined by Scilingo' (p. 106) The aim of testimonial literature to show the many pasts that were silenced, denied and repressed in a certain political and cultural context, questioning the status quo of the dominant present, is demonstrated in the scene of the sixth chapter successively reproduced.

In this section, using the words of a participant in the authoritarian regime, Scilingo, past event are, thanks to an ideological and political reconceptualization, revealed and condemned. First, the general atmosphere in which society is immersed is shown:

He appeared for the time on March 2, 1995. Every year thereafter, I would remember the date, an unnamed anniversary. It was not a live show, just a photograph and his recorded voice on television. Everyone knew about the broadcast. The ads had been running all week. I didn't watch it with my parents; this was for their private bedroom viewing only, and I knew this without having to ask. I went to my friend Amelia's house to watch. Don't worry, she said, my parents don't know. She didn't add about your Dad, but I understood, and I was thankful. (p. 106)

Scilingo's confession emerges in favor of the victims' truth and confirms the unofficial versions denied by history. Through this translation of events, the author rescues another image of the past and brings it into the present. At the same time, a shift in the configuration of historical reality takes place:

The voice of the man on the tape spoke of requesting to be sent to ESMA, the Escuela Mecánica de la Armada, to serve with the saviours of the nation. The voice did not work in the quarters where subversives were detained, but it did once stumble into the zone by accident and see and hear and smell more than intended. One day, a superior told the voice to take subversives on flights, assuring that these acts were sanctioned by the clergy as Christian and

\footnotetext{
${ }^{1}$ Between 1994 and 1995 the children of the disappeared during the dictatorship began to meet up in La Plata, Córdoba, Rosario, Buenos Aires, in many other Argentine cities, forming groups called H.I.J.O.S. (Hijos (Children) for Identity and Justice against Oblivion and Silence) (Dalmaroni 2004: 969).

${ }^{2}$ Here, reference is made to an Argentine film that highlights the unresolved dilemmas of the dictatorship era. Its plot revolves around the discovery made by Alicia, a history professor, that her daughter, the girl that her husband, Roberto, had brought her one day was kidnapped from a "subversive family" who disappeared during their imprisonment.
} 
humane. 9 He took part in two flights, casting thirty people altogether into the sea. How many others there had been, he couldn't say, but thirty fell from his own hands. The people were drugged and stripped, then thrown out of the airplane, naked and alive. Everyone had participated in such flights, as part of their rotating duties. There were times when the voice paused, broke, lowered, other times when it sailed through details as if reading a shipping list out load. (p. 108)

The passage below contains Perla's reflections which reconstruct her father's past. In her thoughts a hidden reality is materialize that was kept secret to her, a reality that was erased, eliminated from memory in a systematic way. A different figure of her father, who is part of another reality, is presented:

... my father on an airplane, my mother kissing my father good-bye on a Monday morning, have a nice day,call if you're staying late, my father in a dark room with naked bodies, my own self in a dark room with naked bodies, implicated, struggling for breath, unable to get out. My father in my bedroom, kneeling on the floor, begging for something incompressible in flotsam words. He was not there, his shadow not hulking in the dark beside my bed, but still I turned away to face the wall. (p. 112)

The following lines highlight the nexus between discourse and sociopolitical reality, and serve as evidence of the embeddedness of reality in discursive narratives. Perla remembers one of the conversations she had with her father: '[...]Look, hija, even the church said it was just God's work, they said. Separating wheat from chaff. The subversives, you know, they didn't believe in God.' [...] 'We were the ones restoring order. For years this country had no order. You have no idea what a shithole this country was before. It needed to be saved, and people knew it, they even asked for it. Now they criticize. Well, you know what -fuck them. They talk about the suffering of the prisoners, but what about our suffering? What about our sacrifice? Fucking bastards, the lot of them' (p. 118/119) [...] 'There are elements in this country that are not to be trusted. You got to be careful. Especially now that you'll be at the university soon, exposed to more kinds of people.' (p. 121)

The second part of the novel shows, too, the divergence between the two discourses like two different ways of assembling reality. In the eight chapter, Perla reveals that her aunt, her father's sister, was a militant of the ERP10 that could be defined as "a group who fought against the prevailing system of socio-economic relations". Regarding the discursive validation of reality, this group represents the organization of the subversives who compose alternative narratives. In this sense, Perla recalls her mother's words:

Those subversives, Mamá once said, they plagues Argentina like cockroaches in those days, in the early 1970s, you have no idea how bad things got, the violence, the kidnappings, nobody was safe anymore, let me tell you, some people talk badly now against the military but something had to be done. Of course, she didn't mention the violent right-wing groups, like AAA, whom I learned about much later on my own. (p. 166)

In the same paragraph, a reference is made to the Triple A, the Anti-Communist Alliance Argentina (AAA), which was an organization set up by the State itself to eliminate everyone who did not fit into the interpretative pattern of the imposed political and social reality (Rostica 2011). With respect to what is considered historical facts, "the Montoneros Peronist Movement and the Revolutionary Army (ERP) are accounted for as "terrorist" organizations which the Triple A was trying to combat (Paino apud Rostica 2011: 7).

In the ninth chapter, De Robertis, by using an analepsis again, reconstructs a scene in which Perla's mother, under the excuse of protecting her daughter, tries to suffocate the other truth that exist by labelling it as a lie. In this way, it becomes clear that all she wants is to impose her interpretation of the facts and to manipulate the way her little daughter thinks. Something that Perla later realizes:

'I don't know anything about the Chinese'. Mamá sighed. 'It's good you want to learn so much,' she said, though she still tried to steer me back to the children's books, which, she pointed out, would be easier to understand, and which were less likely to be riddled with lies. 'What kind of lies?' 'Various kinds. You have to be careful in the adult aisles; books for grown-ups have lies buried in them, like hidden fangs.' (p. 182) [...] By the time I was in high school, [...] I had discounted the whole notion of lies hidden in books as my mother's attempt to keep a girl away from pages that could intrude on the fragile reality of a house. My mother did not want to see, nor for her daughter to see, certain things that could be written about in books, such as, perhaps, the years when I was small and the nation full of quiet. She didn't know. She knew. She knew. She struggled each day to not-know. I had no way of discerning which it was. She would never tell me the true version, and even if she could I wasn't sure that I could bear to hear it. (p. 183)

In the thirteenth chapter, Perla's father internal monologue relates to the acts of appropriation and manipulation of discourses as well as the elaboration of the representations of reality: 
You don't know that story, do you, hija? Of course you don't, there are so many things you don't know, so many things you can't begin to understand, now where are you, where are you not in the bathroom, not in the hall, your room is in turmoil but you are not in it, the master bedroom is empty and the walls in here are screaming with the lack of you. [...] 'We'll get her back. It's too late. No. She's not our daughter anymore. (p. 257)

\section{By way of conclusion}

In this paper we have exemplified the idea of revisioning the past through translations in the sense Ivekovic gave them: "a form of vital resistance to the hegemonic lines of imposition of meaning" (Ivekovic apud Bielsa 2015: 379). The protagonists of Perla retell, recreate and translate the Argentinian past from a perspective 'from below'. These translations of the past, seen as counter-narratives, challenge the dominant discourses, project counterdiscourses that articulate the 'vision of the defeated', verbalize a truth that rescues from oblivion the violations of the fundamental rights of the individual (Medeiros-Lichem 2014: 8).

As has been pointed out before, the whole of the past is constantly rewritten and reintegrated into present-day realities through translation acts. This new way of understanding history can lead us to the conclusion that the experience of social change should start with studying how history was translated by Power, and how meanings were established within a given reality, and then challenge, question and rewrite them by introducing visions of reality that are different from the visions of those in power. In this sense, we can add that historiography does not only imply the elaboration of a specific past, but also defines a possible future.

According to what we have observed through our analysis, translation can be a medium for reconceptualizing the present as well, because it can be used to disrupt, displace, relocate, and put powerful narratives into a new frame in order to change what seems to be immutable. In this sense, translation "as an intellectual activity can be put to the service of history by allowing us to search deep into the past to rectify facts and hopefully avoid scholarly distortions." (Bandia 2009: 226)

This paper invites reflection on the role the translation process plays in constructing reality of both the past and the present, as a way of promoting the critical reading of history, as an act of searching for the voices that have been silenced in the official interpretations of the past. In this context, we focused on the role translation plays in fostering plurality in the social field and providing a balance of perspectives and representations, as a form of protection against a biased way of interpreting reality.

\section{References}

Arrojo, Rosemary. 2002. Writing, Interpreting, and the Power Struggle for the Control of Meaning: Scenes from Kafka, Borges, and Koztolányi. In E. Gentzler, \& M. Tymozcko (Eds.) Translation and Power (pp. 63-80). Amherst/Boston: University of Massachusetts Press.

Attridge, D. (1987). Language as history/history as language: Saussure and the romance of etymology. In Attridge, D. Bennington G., \& Young, R. (Eds.). Post-Structuralism and the Questions of History, (pp. 183-211). Cambridge University Press.

Aurell, J. (2006). Hayden White y la naturaleza narrativa de la historia. Anuario filosófico 39 (3), 625-648.

Baker, M. (2006). Translation and Conflict. London: Routledge.

Baker, M. (Ed.) (2016). Translating dissent. New York and London: Routledge.

Bandin, P. (2006). The Impact of Postmodern Discourse on the History of Translation. In Bastin, G., \& Bandia P. (Eds.), Charting the Future of Translation History, (pp. 45-59). Ottawa: University press.

Barthes, R. (1957). Mythologies. Paris: Éditions du Seuil.

Barthes, R. (1984/1994). The Rustle of Language. Oxford: Blackwell. Trans. Richard Howard.

Bassnett, S., \& Trivedi H. (Eds.). (1999). Post-colonial Translation. Theory and Practice. London: Routledge.

Baudrillard, J. (1972). Pour Une Critique de L’Économie Politique du Signe. Paris: Gallimard.

Berger, P., \& Thomas, Luckmann. (1966). The Social Construction of Reality. London: Penguin.

Bermann, S. (2014). Performing Translation. In Bermann, S., \& Porter C. (Eds.), A Companion to Translation Studies (pp. 285-297). Chichester: Wiley Blackwell.

Bermann, S. \& Porter C. (Eds.) (2014). A Companion to Translation Studies. Chichester: Wiley Blackwell.

Bielsa, E. (2006). Cosmopolitanism and Translation. Investigations into the Experience of the Foreign. London and New York: Routledge.

Bourdieu, P. (1991). Language and Symbolic Power. Cambridge, MA: Harvard University press. Trans. Gino Raymond a. Matthew Adamson.

Butler, J. (1997). Excitable Speech: A Politics of the Performative. New York/ London: Routledge.

Denman, F. (2012). Translation, Philosophy, and Language: What Counts? In L. Foran (Ed.). Translation and Philosophy (pp. 157-173). Frankfurt am Main: Peter Lang.

De Robertis, C. (2012). Perla. NY: Vintage Books.

Duch, L. (2002). Mite i naració. Anàlisi: Cuaderno de comunicación y cultura, 25, 153-169. 
Foucault, M. (1996). Les Mots et Les Choses. Une Archeology Des Sciences Humans. Paris: Gallimard.

García, V. (2016). Testimonio y ficción en la Argentina de la postdictadura. Los relatos del sobreviviente-testigo. Revista Chilena de Literatura, 93, 73-100.

Gentzler, E., \& Tymoczko M. (Eds.) (2002). Translation and Power. Amherst/Boston: University of Massachusetts Press.

Gentzler, E. (2017). Translation and rewriting in the age of post-translation studies. New York and London: Routledge.

Hermans, T. (2006). Translating Others. Manchester: St. Jerome.

Katan, D. (2018). Defining culture, defining translation. In O. Carbonell i Cortés, \& S. Harding (Eds.), The Routledge Handbook of Translation and Culture (pp. 21-37). New York: Routledge.

Levy, D. \& Sznaider N. (2002). Memory Unbound: The Holocaust and the Formation of Cosmopolitan Memory. European Journal of Social Theory, 5 (1), 87-106.

Lowe, E. (2014). Revisiting Re-translation: Re-creation and Historical Revision. In Bermann, S., \& Porter, C. (Eds.), A Companion to Translation Studies (pp. 413-424). Chichester: Wiley Blackwell.

Marais, K. (2019). A (Bio) Semiotic Theory of Translation. New York: Routledge.

Morley, N. (1999). Writing Ancient History. Ithaca, N.Y.: Cornell University Press.

Potter, J. (1996/1998). Representing Reality. Discourse, Rhetoric, and Social Construction. London: Sage.

Rorty, R. (1967/1992). The Linguistic Turn: Recent Essays in Philosophical Method. (2nd. ed.) Chicago, IL, and London: The University of Chicago Press.

Salmon, C. (2013). Storytelling: la máquina de fabricar historias y formatear las mentes. Barcelona: Península. Trans. Inés Bértolo Fernández.

Spivak, G. (1988/1993). Can the Subaltern Speak? In Williams P., \& Christman L. (Eds.), Colonial Discourse and Post-Colonial Theory. A Reader, (pp. 66-111). Hertfordshire: Pentice Hall/ Harvester Wheatsheaf.

Steiner, G. (1998). After Babel: Aspects of Language and Translation. Oxford University Press.

Tymoczko, M. (2007). Enlarging Translation, Empowering Translators. Manchester: St. Jerome.

Vidal, A. (2010). Traducción y asimetría. Frankfurt am Main: Peter Lang.

Vidal, A. (2018). Power. In O. Carbonell i Cortés, \& S. Harding (Eds.), The Routledge Handbook of Translation and Culture (pp. 79-96). New York: Routledge.

Vidal, A. (2019). Violins, violence, translation: looking outwards. The Translator, 25, 1-11.

White, H. (2002). The Historical Text as Literary Artifact. In Richardson, B. (Ed.), Narrative Dynamics: Essays on Time, Plot, Closure, and Frames, (pp. 191-210). Ohio State UP: Columbus.

Zizek, S. (2002). Welcome to the Desert of the Real. London: Verso. 